\title{
Potency of Bacillus Subtilis and Lysinibacillus Mixed With Silica Nano Particles and Carbon Fiber in Controlling Potato Leaf Blight Disease [Phytophthora infestans (Mont.) de Bary]
}

\author{
Hersanti $^{*}$, Fitri Widiantini ${ }^{1}$, Kirana Sonya Harviana ${ }^{2}$ \\ ${ }^{1}$ Agrotechnology Study Program, Agriculture Fakulty, Universitas Padjadjaran, Jatinangor, West Java, Indonesia, 40363 \\ ${ }^{2}$ Alumny of Agrotechnology Study Program, Agriculture Fakulty, Universitas Padjadjaran, Jatinangor, West Java, Indonesia, 40363 \\ *Alamat korespondensi: hersanti09@gmail.com
}

Received July 11, 2019; revised September 30, 2019; accepted December 16, 2019

\begin{abstract}
Leaf blight disease caused by Phytohthora infestans is one of the major diseases on potato plant. To control the disease farmers usually use synthetic fungicides. However, the excessive use of synthetic fungicides may cause negative impacts on the environment. One of the alternative control methods which is more environtmentally friendly is the use of antagonistic microbes. In this experiment, Bacillus subtilis and Lysinibacillus sp. were formulated with carbon fiber as a carrier and enriched with nano silica as a micro nutrient, to find out the ability of the bacteria in suppressing leaf blight disease on potato plant. The experiment was carried out in the experimental field in Lembang, Bandung Barat, Jawa Barat. The experiment was arranged in the randomized block design consisted of nine treatments and four replications. Density of B.subtilis and Lysinibacillus sp. were $10^{11} \mathrm{cfu} / \mathrm{ml}$. The formulation was applied 3 times, on planting, 2 weeks and 4 weeks after planting. The results showed that the application of B. subtillis and Lysinibacillus sp. were able to suppress leaf blight disease, with the disease inhibition $36,6 \%$ and $32,7 \%$ respectively. The combination treatment of $B$. subtilis in silica nano and carbon fiber was able to suppress leaf blight disease on potato plant higher compared to the application of bacteria without nano silica and carbon fiber, with the disease inhibition up to $51,2 \%$.
\end{abstract}

Keyword : antagonist microbes, carrier, leaf blight, nano silica

\section{ABSTRAK}

Kemampuan Bacillus subtilis dan Lysinibacillus dalam Silika Nano dan Serat Karbon untuk Mengendalikan Penyakit Hawar Daun [Phytophthora Infestans (Mont.) de Bary] pada Tanaman Kentang

Penyakit hawar daun yang disebabkan oleh Phytophthora infestans merupakan salah satu penyakit utama yang menyerang tanaman kentang. Metode pengendalian yang umumnya digunakan petani adalah pestisida sintetik. Namun jika penggunaannya dilakukan secara berlebihan, akan mengakibatkan dampak negatif terhadap lingkungan. Salah satu alternatif pengendalian penyakit tanaman yang ramah lingkungan adalah dengan menggunakan mikroba antagonis. Pada penelitian ini Bacillus subtilis dan Lysinibacillus sp. diformulasikan dengan bahan pembawa berupa serat karbon dan diperkaya dengan unsur hara mikro berupa silika yang berukuran nano dengan tujuan untuk mengetahui kemampuan bakteri dalam menekan perkembangan penyakit hawar daun pada tanaman kentang. Percobaan dilakukan di lahan percobaan Kecamatan Lembang, Kabupaten Bandung Barat, Jawa Barat. Percobaan dilakukan dengan metode rancangan acak kelompok yang terdiri dari sembilan perlakuan dan tiga ulangan. Kerapatan B.subtilis dan Lysinibacillus sp. yang digunakan adalah $10^{11} \mathrm{cfu} / \mathrm{ml}$. Aplikasi formulasi dilakukan tiga kali, yaitu saat penanaman, 2 minggu setelah tanam dan 4 minggu setelah tanam. Hasil percobaan menunjukkan bahwa aplikasi B.subtilis dan Lysinibacillus sp. mampu menekan perkembangan penyakit hawar daun dengan persentase penghambatan masing-masing 36,6\% dan 32,7\%. Perlakuan campuran B.subtilis pada silika nano dan serat karbon dalam menekan penyakit hawar daun pada tanaman kentang memiliki persentase penghambatan lebih tinggi dibandingkan aplikasi bakteri tanpa silika nano dan serat karbon, dengan persentase penghambatan sebesar $51,2 \%$.

Kata kunci $\quad$ : Mikroba antagonis, bahan pembawa, busuk daun, silica nano

\section{PENDAHULUAN}

Kentang termasuk ke dalam kelompok makanan pokok dunia bersama dengan gandum, jagung dan beras (Respati dkk., 2013). Menurut Badan Pusat Statistik (2015), rata-rata produktivitas kentang nasional pada tahun 2014 sebesar 17,67 ton per hektar, lebih rendah dibandingkan dengan potensi tanaman kentang yang dapat mencapai 25 - 30 ton per hektar. Salah satu penyebab rendahnya produktivitas kentang di Indonesia disebabkan oleh penyakit tanaman (Semangun, 2006).

Salah satu penyakit tanaman kentang adalah hawar daun yang disebabkan oleh Phytophthora infestans. Pengendalian penyakit yang dilakukan saat ini masih mengandalkan pestisida sintetik dengan bahan aktif 
mankozeb, propineb, difenokonazole dan bahan aktif lainnya yang dinilai dapat lebih cepat mengendalikan pertumbuhan patogen (Sumardiyono, 2008).

Penggunaan pestisida sintetik secara terusmenerus, akan menimbulkan berbagai permasalahan baik bagi lingkungan maupun makhluk hidup di sekitarnya. Salah satu dampak negatif pestisida terhadap lingkungan adalah adanya residu pestisida di dalam tanah yang dapat meracuni organisme nontarget, terbawa ke sumbersumber air dan meracuni lingkungan sekitar (Djunaedy, 2009). Oleh sebab itu, dibutuhkan pengendalian yang efektif dan ramah lingkungan seperti pengendalian biologi yang memanfaatkan agen pengendali hayati (APH) dari kelompok mikroba antagonis (Hersanti dkk., 2009).

Mikroba antagonis yang dapat digunakan sebagai agen pengendali hayati berasal dari kelompok bakteri, cendawan maupun virus (Hanudin dkk., 2012). Beberapa bakteri antagonis yang dapat digunakan sebagai APH antara lain Bacillus subtilis dan Lysinibacillus sp. (Hersanti dkk., 2009 serta Istifadah dkk., 2014).

Menurut Choudhary \& Johri (2008), bakteri $B$. subtilis memiliki kemampuan sebagai agen pengendali hayati melalui mekanisme antibiosis, sekresi enzim pelisis dan penginduksi ketahanan sistemik (Induced Systemic Resistance). Sedangkan Lysinibacillus sp. merupakan bakteri yang dapat menghasilkan enzim kitinase yang merupakan anti-fungal yang mampu melawan patogen (Singh et al., 2012). Berdasarkan hal tersebut, B. subtilis dan Lysinibacillus sp. memiliki potensi untuk digunakan sebagai bahan aktif pembuatan formulasi APH.

Penggunaan formulasi APH umumnya terdiri dari bahan aktif, bahan pembawa dan bahan tambahan. Formulasi APH berbahan aktif bakteri dengan bahan pembawa yang kurang tepat, akan mengakibatkan mikroba antagonis yang digunakan tidak dapat bertahan hidup dalam jangka waktu yang panjang (Aida, 2016). Penggunaan bahan pembawa ini dilakukan untuk memudahkan aplikasi, mempertahankan kondisi dan diharapkan mampu meningkatkan aktivitas mikroba antagonis (Wartono dkk., 2012). Salah satu bahan pembawa yang tepat adalah serat karbon.

Serat karbon ukuran 80 mesh $(0,177 \mathrm{~mm})$ merupakan ukuran yang telah digunakan dan viabel saat dicampurkan dengan bakteri antagonis. Aida (2016) melaporkan bahwa bakteri Pseudomonas fluorescens viabel pada formulasi serat karbon berukuran 80 mesh. Viabilitas merupakan kemampuan suatu individu untuk hidup yang ditandai dengan pertumbuhannya.

Bahan tambahan yang dapat digunakan pada formulasi APH antara lain unsur hara. Salah satu unsur hara yang dapat digunakan yaitu silika $(\mathrm{Si})$, dimana $\mathrm{Si}$ dapat membantu proses stimulasi fotosintesis dan menyuburkan tanah. Selain itu, $\mathrm{Si}$ juga mampu memperkuat jaringan tanaman sehingga dapat lebih tahan terhadap serangan patogen (Yuliani dkk., 2014). Hasil penelitian Amrullah (2013) menunjukkan bahwa penggunaan silika nano memiliki hasil yang berbeda nyata dibandingkan dengan kontrol pada pengamatan tinggi tanaman, jumlah anakan maupun jumlah malai tanaman padi.

Hasil penelitian Ruhyaman dkk. (2017) dan Hersanti dkk. (2017) menunjukkan penggunaan formulasi silika nano 3\% dan serat karbon 80 mesh 5\% yang dicampurkan dengan bakteri B. subtilis atau Lysinibacillus $\mathrm{CKU}_{3}$ mampu menekan pertumbuhan Ralstonia solanacearum secara in-vitro, yang ditandai dengan adanya zona hambat.

Tujuan penelitian adalah unruk menguji kemampuan B. subtilis dalam serat karbon dan nano silica unetuk mengendalikan penyakit busuk daun pada tanaman kentang.

\section{BAHAN DAN METODE}

Percobaan dilaksanakan di Laboratorium Fitopatologi, Departemen Hama dan Penyakit Tumbuhan, serta lahan percobaan di Baruajak Kecamatan Lembang, Kabupaten Bandung Barat, Jawa Barat dengan ketinggian \pm 1200 meter di atas permukaan laut pada bulan November 2017 sampai dengan bulan Juni 2018.

Alat-alat yang digunakan dalam percobaan ini adalah plastik cling wrap, kapas, pembakar bunsen, tabung reaksi, jarum ose, batang L, laminar air flow (LAF), sentrifuge, gelas ukur, labu Erlenmeyer, vortex shaker, tisu, oven, semprotan, autoclave, selotip, spidol, label, beaker glass, pipet, mata pipet, pematik, gunting, mulsa plastik hitam perak (MPHP), polybag, jarum, cangkul, buku catatan, dan alat tulis.

Bahan-bahan yang digunakan dalam percobaan ini adalah adalah isolat Bacillus subtilis dan Lysinibacillus $\mathrm{CKU}_{3}$ asal Cikajang Garut, milik Ir. Noor Istifadah, M.CP.,Ph.D. koleksi Departemen Hama dan Penyakit Tumbuhan Fakultas Pertanian Universitas Padjadjaran, suspensi serat karbon ukuran 80 mesh $(0,177$ $\mathrm{mm})$, silika berukuran nano buatan Pusat Riset Institusi Nano Teknologi dan Graphene (PRINT - G) Universitas Padjadjaran, media nutrient agar (NA), nutrient broth (NB), potato dextrose agar (PDA), aquades steril, alkohol, insektisida berbahan aktif Propinep 80\%, fungisida berbahan aktif Mankozeb $80 \%$, bibit kentang varietas Granola G0, pupuk kotoran ayam, arang sekam, tanah dan air.

Percobaan dilaksanakan dengan metode eksperimen Rancangan Acak Kelompok (RAK) yang terdiri dari sembilan perlakuan dan tiga ulangan. Setiap ulangan terdiri dari 3 tanaman, sehingga jumlah seluruhnya adalah 81 tanaman. Perlakuan yang diuji adalah aplikasi formulasi agen biokontrol yang disajikan pada Tabel 1. 
Tabel 1. Rancangan perlakuan

\begin{tabular}{c|l}
\hline Kode & \multicolumn{1}{|c}{ Perlakuan } \\
\hline $\mathrm{A}$ & B. subtilis \\
$\mathrm{B}$ & Lysinibacillus $\mathrm{CKU}_{3}$ \\
$\mathrm{C}$ & B. subtilis + Lysinibacillus $\mathrm{CKU}_{3}$ \\
$\mathrm{D}$ & $\begin{array}{l}\text { B. subtilis + serat karbon 80 mesh 5\% + } \\
\text { silika nano 3\% }\end{array}$ \\
$\mathrm{E}$ & $\begin{array}{l}\text { Lysinibacillus } \mathrm{CKU}_{3}+\text { serat karbon 80 } \\
\text { mesh 5\% + silika nano 3\% }\end{array}$ \\
$\mathrm{F}$ & B. subtilis + Lysinibacillus $\mathrm{CKU}_{3}+$ serat \\
$\mathrm{G}$ & karbon 80 mesh 5\% + silika nano 3\% \\
& Serat karbon 80 mesh 5\% + silika nano \\
$\mathrm{H}$ & 3\% \\
$\mathrm{I}$ & Fungisida \\
& Kontrol \\
\hline
\end{tabular}

\section{Persiapan Media Tanam}

Media tanam yang digunakan adalah campuran tanah dan pupuk kotoran ayam dengan perbandingan 1:2 per kg dan dimasukan ke dalam polybag ukuran $30 \mathrm{~cm} \mathrm{x}$ $20 \mathrm{~cm}$. Media tanah yang digunakan sebelumnya dipasteurisasi dengan cara dikukus.

\section{Pembuatan Formulasi}

Persiapan isolat bakteri B. subtilis dan Lysinibacillus sp. isolat $\mathrm{CK} \quad \mathrm{U}_{3}$ dimulai dengan perbanyakan bakteri di dalam cawan petri berisi media nutrient agar (NA). Perbanyakan dilakukan secara aseptik di dalam Laminar Air Flow, yaitu dengan cara mengambil 1 (satu) ose biakan murni dari masing-masing bakteri, kemudian digoreskan pada permukaan media NA yang ada di dalam cawan petri, dan diinkubasikan selama 48 jam pada suhu ruangan.

Pembuatan suspensi bakteri $B$. subtilis dan Lysinibacillus sp. isolat $\mathrm{CK} \mathrm{U}_{3}$ dilakukan dengan cara menambahkan $5 \mathrm{ml}$ aquadest steril pada media yang telah berisi biakan bakteri. Selanjutnya, bakteri dipanen dengan menggunakan batang L secara perlahan, sehingga membentuk suspensi dengan aquadest. Suspensi bakteri lalu dimasukkan ke dalam media nutrient broth (NB), dan diinkubasikan dengan shaker selama 13 jam hingga mencapai kerapatan lebih dari $10^{7} \mathrm{cfu} / \mathrm{ml}$. Suspensi silika nano yang digunakan memiliki ukuran $10 \mathrm{~nm}$ dengan konsentrasi 3\%, dan serat karbon 80 mesh $(0,177 \mathrm{~mm})$ dengan konsentrasi $5 \%$.

\section{Pelaksanaan Percobaan}

Benih kentang varietas Granola yang digunakan dilukai dengan jarum steril sedalam $\pm 1 \mathrm{~cm}$ pada sisi ubi. Kemudian benih kentang direndam dalam formulasi dengan volume $15 \mathrm{ml}$ selama 30 menit. Setelah itu benih dikeringanginkan agar bakteri dapat mengkolonisasi.
Setelah benih kering, benih ditanam dan campuran sisa perendaman disiramkan pada sekitar lubang tanam.

Aplikasi susulan dilakukan saat tanaman berumur 2 minggu setelah tanam (MST) dan 4 MST. Pengaplikasian dilakukan dengan cara formulasi disiramkan pada sekitar batang sebanyak $5 \mathrm{ml}$ per polybag saat tanaman berumur 2 MST dan $10 \mathrm{ml}$ perpolybag saat tanaman berumur 4 MST. Aplikasi fungisida pada perlakuan $\mathrm{H}$ dilakukan saat penyakit hawar daun muncul pertama kali pada penanaman. Pemeliharaan yang dilakukan yaitu penyiraman serta penyiangan gulma yang dilakukan secara manual dan dilakukan setiap minggu.

\section{Pengamatan}

Pengamatan dilakukan untuk mengetahui:

1) Masa inkubasi penyakit hawar daun, yang diamati setiap hari sejak penanaman hingga gejala muncul

2) Intensitas penyakit hawar daun diamati pada semua daun kentang dengan interval waktu tujuh hari, sejak muncul gejala pada tanaman hingga 9 MST. intensitas penyakit hawar daun dapat dihitung dengan rumus:

Keterangan :

$$
\mathrm{P}=\frac{\sum(n \times v)}{N \times Z} \times 100 \%
$$

$\mathrm{P} \quad=$ intensitas kerusakan tanaman $(\%)$

$\mathrm{n}_{\mathrm{i}} \quad=$ jumlah tanaman yang memiliki nilai kerusakan (v) yang sama

$\mathrm{v}_{\mathrm{i}} \quad=$ nilai kerusakan berdasarkan luas seluruh bagian tanaman yang terserang dengan skor, yaitu :

0 : tidak terdapat kerusakan

1 : kerusakan tanaman $>0-\leq 10 \%$

2 : kerusakan tanaman $>10-\leq 20 \%$

3 : kerusakan tanaman $>20-\leq 40 \%$

4 : kerusakan tanaman $>40-\leq 60 \%$

5 : kerusakan tanaman $>60 \%$

$\mathrm{N} \quad=$ jumlah tanaman yang diamati

$\mathrm{Z} \quad=$ nilai skor tertinggi

Data intensitas penyakit hawar daun digunakan untuk menghitung nilai area under diseases progress curve (AUDPC) dengan rumus:

$$
A U D P C=\sum_{n=1}^{n-1}\left\{\left(\frac{Y i+Y i+1}{2}\right)\right\}(\mathrm{ti}+1-t i)
$$

\section{Keterangan :}

$$
\begin{array}{ll}
\mathrm{Yi} & =\text { data pengamatan ke- } 1 \\
\mathrm{t}_{\mathrm{i}} & =\text { waktu pengamatan ke-1 } \\
\mathrm{Yi}+1 & =\text { data pengamatan } \mathrm{ke}-\mathrm{i}+1 \\
\mathrm{t}_{\mathrm{i}+1} & =\text { waktu pengamatan } \mathrm{ke}-\mathrm{i}+1
\end{array}
$$

Persentase penghambatan dari setiap perlakuan tersebut dihitung dengan menggunakan rumus : 
Penghambatan $=1-\frac{\text { AUDPC perlakuan } \mathrm{i}}{\text { AUDPC kontrol }} \times 100 \%$

3) Pertumbuhan tanaman yang dilakukan adalah tinggi tanaman dan jumlah daun sejak tanaman berumur 2 MST hingga tanaman berumur 9 MST, dengan interval pengamatan 7 hari.

\section{HASIL DAN PEMBAHASAN}

\section{Inkubasi Penyakit Hawar Daun}

Masa inkubasi adalah waktu sejak awal penanaman yang diamati setiap hari hingga pertama kali munculnya gejala penyakit pada tanaman. Berdasarkan hasil pengamatan secara morfologis, kemunculan awal gejala hawar daun terjadi pada 18 hari setelah tanam (HST) pada setiap perlakuan. Gejala penyakit diawali dengan munculnya bercak cokelat kehitaman pada tepi daun (Gambar 1). Hal ini sesuai dengan pernyataan Forbes et al., (2014) bahwa gejala hawar daun diawali dengan bercak berwarna cokelat gelap yang tidak beraturan pada tepi daun.

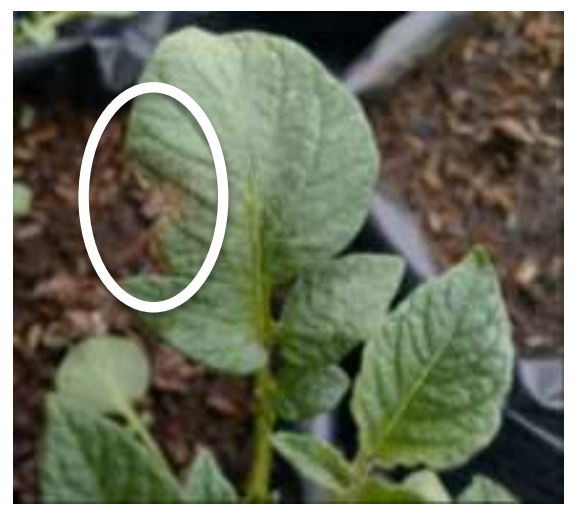

Gambar 1. Gejala hawar daun di lapangan

Tabel 1. Masa inkubasi penyakit hawar daun

\begin{tabular}{ccc}
\hline & $\begin{array}{c}\text { Masa inkubasi } \\
(\text { HST })\end{array}$ & $\begin{array}{c}\text { Intensitas Penyakit } \\
(\%)\end{array}$ \\
\hline $\mathrm{A}$ & 18 & 2,2 \\
\hline $\mathrm{B}$ & 18 & 3,0 \\
\hline $\mathrm{C}$ & 18 & 2,2 \\
\hline $\mathrm{D}$ & 18 & 0,7 \\
\hline $\mathrm{E}$ & 18 & 0 \\
\hline $\mathrm{F}$ & 18 & 1,5 \\
\hline $\mathrm{G}$ & 18 & 0 \\
\hline $\mathrm{H}$ & 18 & 2,2 \\
\hline $\mathrm{I}$ & 18 & 3,7
\end{tabular}

Keterangan : Nilai yang diikuti oleh huruf yang sama dalam tiap kolom menunjukkan tidak berbeda nyata menurut uji Duncan pada taraf 5\%. A : B. subtilis; B : Lysinibacillys sp.; C : B. sibtilis + Lysinibacillus sp.;D : B. subtilis + silika nano + serat karbon; E : Lysinibacillus sp. + silika nano + serat karbon; F : B. subtilis + Lysinibacillus sp. + silika nano + serat karbon; G : Silika nano + serat karbon; H : Pestisida; I : Kontrol

Tabel 1 menunjukkan bahwa penggunaan formulasi belum mampu menunda masa inkubasi penyakit hawar daun. Hal ini terjadi, diduga karena formulasi yang digunakan belum beradaptasi dengan lingkungan. Menurut Sulistiani (2009) penggunaan bakteri antagonis membutuhkan waktu \pm 3 minngu untuk beradaptasi pada lingkungan yang baru.

\section{Intensitas Penyakit Hawar Daun pada Tanaman Kentang}

Intensitas penyakit hawar daun (Gambar 2) menunjukkan fluktuasi pada setiap pengamatan.

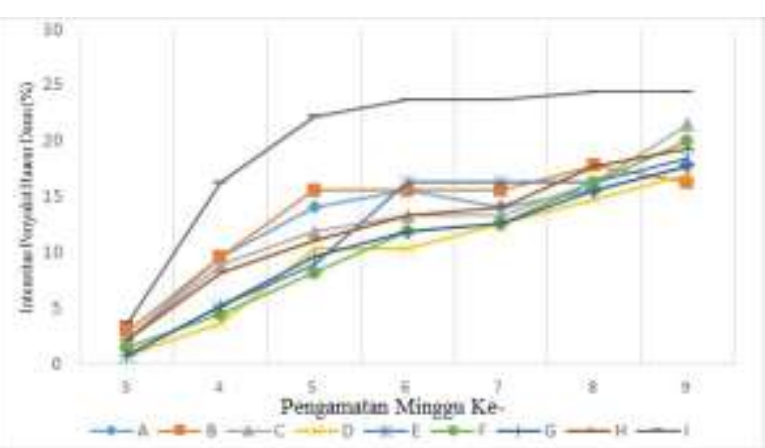

Gambar 2. Intensitas penyakit hawar daun tanaman kentang

Keterangan : Nilai yang diikuti oleh huruf yang sama dalam tiap kolom menunjukkan tidak berbeda nyata menurut uji Duncan pada taraf 5\%. A : B. subtilis; B : Lysinibacillys sp.; C : B. sibtilis + Lysinibacillus $\mathrm{sp} . ; \mathrm{D}$ : B. subtilis + silika nano + serat karbon; E : Lysinibacillus sp. + silika nano + serat karbon; F : B. subtilis + Lysinibacillus sp. + silika nano + serat karbon; G : Silika nano + serat karbon; H : Pestisida; I : Kontrol

Fluktuasi ini terjadi karena banyaknya daun yang gugur dan pertumbuhan daun baru. Selain curah hujan yang tinggi saat penelitian, kelembaban di sekitar penanaman juga terjadi dipengaruhi dengan tumbuhnya gulma di sekitar tanaman kentang. Menurut Forbes et al., (2014) curah hujan dan kelembaban yang tinggi mendukung perkembangan penyakit hawar daun saat penanaman.

Data intensitas penyakit hawar daun mengalami penurunan atau intensitas penyakit yang tetap. Hal ini diduga terjadi karena aplikasi susulan formulasi yang dilakukan saat tanaman berumur 4 MST mampu 
mengendalikan pertumbuhan patogen $P$. infestans. Adapun perlakuan yang mengalami penurunan adalah perlakuan A (B. subtilis) pada 6 MST dan perlakuan B (Lysinibacillus sp.) pada 8 MST. Pengulangan aplikasi formulasi diharapkan mampu meningkatkan kemampuan bakteri antagonis dalam mengendalikan penyakit tanaman. Hal ini didukung oleh pernyataan Wachjadi dkk. (2013) yang menyatakan bahwa pengulangan aplikasi agensi pengendali hayati mampu meningkatkan populasi bakteri antagonis sehingga dapat meningkatkan persaingan serta meningkatkan jumlah antibiotik, sehingga mampu meningkatkan kemampuan antagonis dalam mengendallikan patogen.

Tabel 2. Data AUDPC penyakit hawar daun pada tanaman kentang

\begin{tabular}{ccc} 
& AUDPC & Penghambatan (\%) \\
\hline A & $552,2 \mathrm{a}$ & 36,6 \\
\hline B & $585,9 \mathrm{a}$ & 32,7 \\
\hline $\mathrm{C}$ & $528,9 \mathrm{a}$ & 39,3 \\
\hline $\mathrm{D}$ & $425,2 \mathrm{a}$ & 51,2 \\
\hline E & $508,2 \mathrm{a}$ & 41,7 \\
\hline F & $448,5 \mathrm{a}$ & 48,5 \\
\hline G & $448,5 \mathrm{a}$ & 48,5 \\
\hline H & $526,3 \mathrm{a}$ & 39,6 \\
\hline I & $871,1 \mathrm{~b}$ & 0 \\
\hline
\end{tabular}

Keterangan : Nilai yang diikuti oleh huruf yang sama dalam tiap kolom menunjukkan tidak berbeda nyata menurut uji Duncan pada taraf 5\%

Keterangan : Nilai yang diikuti oleh huruf yang sama dalam tiap kolom menunjukkan tidak berbeda nyata menurut uji Duncan pada taraf 5\%. A : B. subtilis; B : Lysinibacillys sp.; C : B. sibtilis + Lysinibacillus sp.;D : B. subtilis + silika nano + serat karbon; E : Lysinibacillus sp. + silika nano + serat karbon; F : B. subtilis + Lysinibacillus sp. + silika nano + serat karbon; G : Silika nano + serat karbon; $\mathrm{H}$ : Pestisida; I : Kontrol

Nilai AUDPC yang kecil memiliki persentase penghambatan yang besar terhadap penyakit hawar daun. Hasil analisis AUDPC pada Tabel 4 menunjukkan bahwa semua perlakuan memiliki hasil yang berbeda nyata dibandingkan dengan control, akan tetapi antar perlakuan yang di uji tidak berbeda nyata. Persentase penghambatan penyakit terendah terdapat pada perlakuan B (Lysinibacillus sp.) sebesar 32,7\%, sedangkan persentase penghambatan penyakit tertinggi adalah perlakuan D $(B$. subtilis + serat karbon + silika nano) sebesar 51,2\% dibandingkan dengan perlakuan kontrol. Hasil tersebut sesuai dengan hasil penelitian Hersanti dkk. (2016) yang menunjukkan bahwa penggunaan $B$. subtilis mampu menghambat perkembangan penyakit bercak daun cokelat sebesar $40,59 \%$.

Formulasi APH dengan bahan tambahan silica nano dan serat karbon memiliki persentase penghambatan yang lebih tinggi dibandingkan dengan formulasi APH tanpa silica nano dan serat karbon (Tabel 4Hal ini diduga penggunaan silika nano selain berguna sebagai unsur hara mikro juga mampu mengendalikan perkembangan patogen $P$. infestans. Penggunaan silika juga mampu menekan intensitas penyakit pada tanaman padi (Makarim, 2007). Selain itu, penggunaan serat karbon yang dicampurkan dengan bakteri antagonis diduga mampu menjadi bahan pembawa yang tepat dalam pembuatan formulasi, sehingga dapat mempertahankan populasi bakteri dan menjaga kemampuan bakteri dalam menekan perkembangan penyakit.

\section{Pertumbuhan Tanaman}

Aplikasi formulasi APH pada tanaman kentang mampu meningkatkan tinggi tanaman kentang dibandingkan dengan kontrol (Gambar 8). Hal ini menunjukkan bahwa penggunaan bakteri antagonis maupun silika nano dan serat karbon mampu meningkatkan tinggi tanaman kentang. Hal ini sesuai dengan pernyataan Surette et al., (2003) yang melaporkan bahwa pemberian bakteri antagonis mampu memberikan pengaruh yang menguntungkan terhadap pertumbuhan tanaman. Aplikasi susulan formulasi yang dilakukan saat tanaman kentang berumur 4 MST memberikan pengaruh yang nyata terhadap tinggi tanaman kentang. Hal ini ditunjukkan pada pengamatan saat tanaman berumur 6 MST, terjadi peningkatan tinggi tanaman pada semua perlakuan.

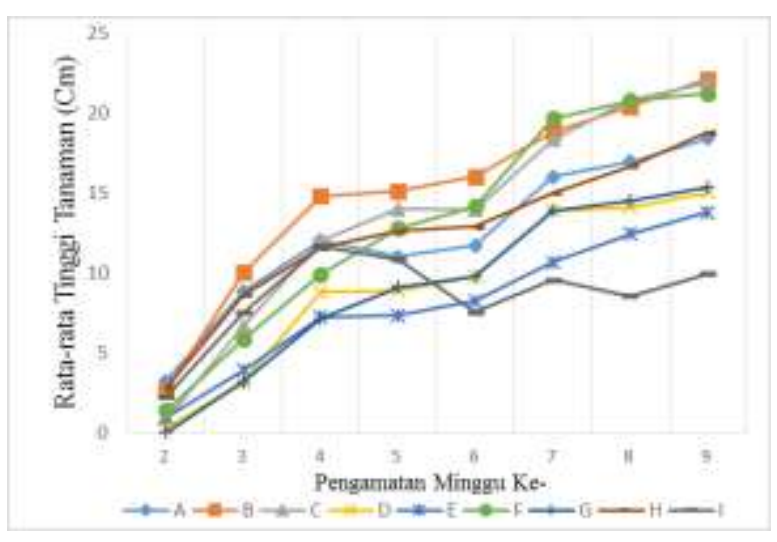

Gambar 8. Pengaruh perlakuan terhadap tinggi tanaman kentang.

Keterangan : Nilai yang diikuti oleh huruf yang sama dalam tiap kolom menunjukkan tidak berbeda nyata menurut uji Duncan pada taraf 5\%. A : B. subtilis; B : Lysinibacillys sp.; C : B. sibtilis + Lysinibacillus sp.;D : B. subtilis + silika nano + serat karbon; E : Lysinibacillus 
sp. + silika nano + serat karbon; F : B. subtilis + Lysinibacillus $\mathrm{sp} .+$ silika nano + serat karbon; G : Silika nano + serat karbon; $\mathrm{H}$ : Pestisida; I : Kontrol

\section{KESIMPULAN}

Bakteri B. subtilis yang dicampur dengan serat karbon 5\% dan silika nano 3\% mampu mengendalikan penyakit hawar daun pada tanaman kentang dengan persentase penekanan sebesar $51,2 \%$.

\section{UCAPAN TERIMA KASIH}

Penelitian ini didanai dari Academic Leadership Grant (ALG) Universitas Padjadjaran dengan nomor kontrak No. 855/UN6.3.1/PL/2017.

\section{DAFTAR PUSTAKA}

Aida, M.N. 2016. Viabilitas Bakteri Pseudomonas fluorescens Mig. dalam Formulasi Serat Karbon 80 Mesh. [Skripsi] Universitas Padjadjaran (tidak dipublikasikan), $55 \mathrm{hlm}$.

Amrullah. 2013. Peningkatan produktivitas tanaman padi (Oryza sativa L.) di lahan sawah melalui pemberian nano silika. Hal : $70-83$.

Badan Pusat Statistik. 2015. Statistik Produksi Hortikultura Tahun 2014. Direktorat Jenderal Hortikultura. Kementrian Pertanian.

Choudhary, D.K. \& B.N. Johri. 2008. Interactions of bacillus spp. and plants-with special reference to induced systemic resistance (ISR). Microbiological Research, 164 : 493 - 513.

Djunaedy, A. 2009. Biopestisida sebagai pengendali organisme penganggu tanaman (OPT) yang ramah lingkungan. Embryo, 6(1) : 88 - 95 .

Forbes, G.A., W. Perez \& J.A. Piedra. 2014. Field assesment of resistance in potato to Phytophthora infestans. International Potato Center (CIP), 35pp.

Hanudin, B. Marwoto, Hersanti \& Muharam. 2012. Kompatibilitas Bacillus subtilis, Pseudomonas fluorescens, dan Trichoderma harzianum untuk mengendalikan Ralstonia solanacearum pada tanaman kentang. Hortikultura, 22(2) : 173-180.

Hersanti., A. Susanto, N. Istifadah, \& W.R. Pawstri. 2017. Keefektifan bakteri Lysinibacillus sp. dalam formulasi silika nano dan serat karbon untuk menekan perkembangan Ralstonia solanacearum secara In Vitro. Seminar Nasional dan Kongres XXIV Perhimpunan Fitopatologi Indonesia. Kendari, 3-5 Oktober 2017.

Hersanti, L. Djaya, M. Fuser \& H.E. Krestini. 2016. Pengujian bakteri endofit dan plant growth promoting rhizobacteria (PGPR) untuk mengendalikan penyakit layu bakteri (Ralstonia solanacearum) dan busuk daun (Phytphthora infestans) pada tanaman kentang. Seminar nasional perhimpunan fitopatologi Indonesia, $269-276$.

Hersanti., R.T. Rupendi, A. Purnama, Hanudin, B. Marwoto, \& O.S. Gunawan. 2009. Penapisan beberapa isolat Pseudomonas fluorescens, Bacillus subtilis dan Trichoderma harzianum yang bersifat antagonistik terhadap Ralstonia solanacearum pada Tanaman Kentang. Agrikutura, 20(3) : 198 - 203.

Istifadah, N., A. Melawati, P. Suryatmana, \& B.N. Fitriatin. 2014. Keefektifan konsorsium mikroba antagonis dan pupuk jayati untuk menekan penyakit rebah semai (Rhizoctonia solani) pada cabai. Agriculture, 1(4): 337 - 345.

Makarim, A.K., E. Suhartatik, \& A. Kartohardjono. 2007. Silikon : hara penting pada sistem produksi padi. Iptek Tanaman Pangan, 2 (2) : 195 - 204.

Ruhyaman, R.R., Hersanti, S. Hartanti, M. Setiawati, \& I.M. Joni. 2017. Efficacy of Bacillus subtilis in nano silica and carbon fiber formulation for control of Ralstonia solanacearum under in vitro conditions. $5^{\text {th }}$ Asian Plant Growth-Promoting Rhizobacteria International Conference for Sustainable Agriculture 2017, 64pp.

Semangun. H. 2006. Pengantar Ilmu Penyakit Tumbuhan. Universitas Gadjah Mada : Yogyakarta. 754 hlm.

Singh, R.K., D.P. Kumar, M.K. Solanki, P. Singh, A.K. Srivastva, S. Kumar, P.L. Kashyap, A.K. Saxena, P.K. Singhal, \& D.K. Arora. 2012. Optimazion of media components for chitiase production by chickpea rhizosphere associated Lysinibacillus fusiformis B-CM18. Basic Microbiology. 52: 1-10.

Sulistiani. 2009. Formulasi spora Bacillus subtilis sebagai agens hayati dan PGPR (Plant Growth Promoting Rhizobacteria) pada berbagai bahan pembawa. [Skripsi] Bogor : Institut Pertanian Bogor, $32 \mathrm{hlm}$.

Sumardiyono, C. 2008. Ketahanan jamur terhadap fungisida di Indonesia. Perlindungan Tanaman Indonesia, 14 (1): 1 - 5.

Surette, M.A., A.V. Sturz, R.R. Lada \& J. Nowak. 2003. Bacterial endophytes in processing carrots (Daucus carota L. var. sativus): their localization, population density, biodiversity and their effects on plant growth. Plant and Soil, 253 : 382 - 390 .

Wachjadi, M., L. Soesanto, A. Manan \& E. Mugiastuti. 2013. Pengujian kemampuan mikroba antagonis untuk mengendalikan penyakit hawar daun dan layu bakteri pada tanaman kentang di daerah endemis. Agrin, 17(2) : $92-102$.

Wartono., Y. Suryadi, \& D.N. Susilowati. 2012. Keefektifan formulasi bakteri Burkholderia 
cepacia isolat E76 terhadap Rhizoctonia solani Kühn pada pertumbuhan tanaman padi di laboratorium. Agrotropika, 17(2) : 39 - 42 .

Yuliani, K., Ngadiwiyana, E. Siswoyo, D.A. Amaliah, Y. Wahyono, \& D. Widianingrum. 2014. pengaruh kombinasi silika dan kitosan berbasis nanoteknologi sebagai bahan dasar pembuatan pupuk nano slow release terhadap penyerapan unsur hara oleh tanaman dalam meningkatkan hasil pertanian di Indonesia. Artikel Ilmiah Teknologi Kimia dan Industri, $1-6$. 